\begin{tabular}{|ll|}
\hline Received & $: 15$ Maret 2020 \\
Revised & $: 2$ April 2020 \\
Accepted & $: 20$ April 2020 \\
Online & $: 25$ April 2020 \\
Published & $: 30$ April 2020
\end{tabular}

\title{
Integrasi Sejarah Matematika dalam Pembelajaran Matematika pada Materi Phytagoras
}

\author{
Rahma Rosaliana Saraswati ${ }^{1, \text { a) }}$, Nabila Nurizzah ${ }^{2, \text { b) }}$ Pipih Pitnawati $^{3, \text { c) }}$, \\ Umi Habibah ${ }^{4, d)}$ \\ ${ }^{1,2}$ Pendidikan Matematika, Fakultas Matematika dan Ilmu Pengetahuan Alama, Universitas Negeri Jakarta \\ ${ }^{3}$ Pendidikan Vokasional Konstruksi Bangunan, Fakultas Teknik, Universitas Negeri Jakarta \\ ${ }^{4}$ Hubungan Masyarakat, Fakultas Ilmu Sosial, Universitas Negeri Jakarta \\ : a)rahma.rosaliana@gmail.com, b)nabila.nrzzh@gmail.com, ${ }^{c}$ pipihpitnawati2904@gmail.com, \\ d)umayrahb11@gmail.com
}

\begin{abstract}
The study aims to know the integration of mathematics history on mathematics learning in phytagoras material to motivate students on mathematics learning. This study is a descriptive qualitative research with data collection of literature review. The integration mathematics history in mathematics learning can be in a form of utilization of problems and solution that is inspired from math history, utilization of anecdote or stories from history to inspire, utilization of mathematics problems in history as a source of question, etc. Mathematical concept was created from necessity to solve problems in daily basis and that concept can grow along with the growing of needs and knowledge by the humans themselves.Mathematics history as an aid in learning process, can give a new experience for the students and make mathematics learning more meaningful because of the relation of daily activities.
\end{abstract}

Keywords: Mathematics History, Motivation To Learn, Phytagoras.

\begin{abstract}
Abstrak
Penelitian ini bertujuan untuk mengetahui pengintegrasian sejarah matematika pada pembelajaran matematika dalam materi phytagoras untuk memotivasi siswa pada pembelajaran matematika. Penelitian ini adalah penelitian kualitatif deskriptif dengan teknik pengumpulan data yang digunakan adalah studi literatur. Pengintegrasian sejarah matematika dalam pembelajaran matematika berarti dapat berupa memanfaatkan masalah dan solusinya yang terinspirasi dari sejarah matematika, memanfaatkan cerita dari sejarah untuk menginspirasi, memanfaatkan masalah-masalah dalam sejarah sebagai sumber soal dan lain-lain. Konsep matematika tercipta didasarkan kepentingan untuk menyelesaikan suatu permasalahan dalamkehidupan seharihari dan berkembang sejalan dengan perkkembangan kebutuhan dan ilmu pengetahuan manusia itu sendiri. Sejarah matematika sebagai media dalam proses belajar, dapat memberikan pengalaman baru bagi siswa serta membuat pembelajaran matematika lebih bermakna karena dihubungkan dengan kehidupan sehari - hari.
\end{abstract}

Kata kunci : Motivasi Belajar, Phytagoras, Sejarah Matematika.

\section{PENDAHULUAN}

Pusat Pengembangan Pendidikan Kemendikbud menyatakan bahwa hasil Ujian Nasional SMP/MTs/sederajat pada tahun 2019 untuk tingkat nasional memiliki persentase siswa yang menjawab benar pada materi geometri hanya sebesar $42,27 \%$, dengan submateri menentukan panjang diagonal bangun ruang memiliki persentase siswa yang menjawab benar sebesar $39,44 \%$ dan submateri menentukan panjang diagonal bangun datar sebesar 46,56\% (Pusat Pengembangan Pendidikan Kemendikbud, 2019). Di sisi lain, kedua submateri tersebut merupakan beberapa contoh 
penerapan teorema phytagoras. Hal ini menunjukan bahwa hasil belajar siswa terhadap penerapan teorema phytagoras masih rendah.

Rendahnya hasil belajar siswa disebabkan oleh beberapa faktor. Faktor-faktor tersebut diantaranya adalah kecerdasan siswa, lingkungan belajar, perhatian siswa, metode mengajar, alat peraga, motivasi belajar, dan self-regulated learning (Siswato, 2017). Adapun yang menjadi fokus utama dari penelitian ini adalah motivasi belajar siswa. Hal ini berdasarkan hasil penelitian sebelumnya yang menyatakan bahwa, terdapat pengaruh yang signfikan antara motivasi belajar terhadap hasil belajar matematika siswa (Aritonang, 2008; Cleopatra, 2015; Hamdu \& Agustina, 2011; Mappeasse, 2009; Setyowati, 2007; Siswato, 2017). Berdasarkan pernyataan tersebut, maka diperlukan strategi yang tepat untuk meningkatkan motivasi belajar siswa.

Salah satu strategi yang dapat dilakukan untuk meningkatkan motivasi belajar siswa yaitu dengan pembelajaran matematika yang diintegrasikan dengan sejarah matematika (Wahyu \& Mahfudy, 2016). Mengintegrasikan sejarah matematika dalam pembelajaran matematika dapat meningkatkan motivasi belajar sebanyak 11\% (Argaswari, 2018). Pada literatur review ini, penelitian difokuskan pada pengintegrasian sejarah matematika dalam pembelajaran matematika materi phytagoras.

\section{METODE}

Penelitian ini adalah penelitian kualitatif dengan teknik pengumpulan data yang digunakan pada penelitian ini adalah studi literatur. Data-data yang digunakan penulis bersumber dari literatur yang relevan dengan kasus permasalahan. Beberapa diantaranya bersumber dari buku referensi, jurnal, dan abstrak hasil penelitian. Data yang telah diperoleh dari studi literatur kemudian dipilih sesuai kebutuhan untuk menyelesaikan permasalahan yang ada. Pengolahan data ini dilakukan dengan mengaitkan data - data yang ada dengan objek gagasan sehingga diperoleh konsep gagasan yang bisa memecahkan permasalahan. Analisis data dalam karya tulis ilmiah ini dilakukan secara deskriptif.

\section{HASIL DAN PEMBAHASAN}

\section{Integrasi Sejarah Matematika}

Sejarah matematika merupakan sekumpulan kejadian yang berkaitan dengan perkembangan matematika pada masa lalu. Bagaimana suatu konsep matematika yang sama berkembang di beberapa tempat berbeda sekaligus disebut sejarah matematika suatu konsep. Oleh sebab itu, sejarah matematika bisa meningkatkan pemahaman terkait konsep dan kenapa konsep matematika tersebut ada. Sejarah matematika merupakan sebuah kajian terkait asal-usul penemuan matematika yang meliputi notasi dan metode matematika di masa lalu.

Belajar matematika tidaklah bermakna jika tidak dihubungkan dengan kehidupan sehari-hari. Hal ini disebabkan dalam kegiatan kehidupan sehari-hari, manusia sering membutuhkan bantuan ilmu matematika, misalnya dalam jual beli, bertani dan lain-lain. Pada dasarnya, matematika lahir dari kehidupan sehari-hari manusia yang berkaitan dengan segala aktivitasnya.

Integrasi sejarah matematika sendiri pada pembelajaran terbagi menjadi tiga kategori, yaitu: (1) mempelajari sejarah matematika, (2) pendekatan belajar yang dikembangkan dari sejarah matematika dalam materi matematika, dan (3) lebih dalam memahami matematika dari segi sejarah matematika (Fiangga, dkk., 2017).

Berdasarkan pernyataan tersebut, pengintegrasian sejarah matematika dalam pembelajaran matematika berarti dapat berupa memanfaatkan masalah dan solusinya yang terinspirasi dari sejarah matematika, memanfaatkan cerita dari sejarah untuk menginspirasi, memanfaatkan masalah-masalah dalam sejarah sebagai sumber soal dan lain-lain.

\section{Teorema Phytagoras}

Teorema Pythagoras merupakan salah satu materi pokok mata pelajaran matematika yang dipelajari siswa SMP kelas VIII pada semester I. Teorema Pythagoras berbunyi, pada suatu segitiga siku-siku berlaku sisi miring kuadrat sama dengan jumlah kuadrat sisi-sisi lainnya. Secara umum, 
jika segitiga $\mathrm{ABC}$ siku-siku di $\mathrm{C}$ maka teorema Pythagoras dapat dinyatakan $\mathrm{AB}^{2}=\mathrm{AC}^{2}+\mathrm{BC}^{2}$. Banyak buku menuliskan teorema ini sebagai $c^{2}=a^{2}+b^{2}$ dengan $c$ adalah sisi miring.

\section{Dalil Kebalikan Teorema Pythagoras}

Jika kuadrat sisi terpanjang atau sisi miring sebuah segitiga sama dengan jumlah kudrat panjang kedua sisinya, maka segitiga tersebut merupakan segitiga siku - siku. Lalu, jika suatu segitiga berlaku $c^{2}=a^{2}+b^{2}$ atau $a^{2}=c^{2}-b^{2}$ atau $b^{2}=c^{2}-a^{2}$, maka segitiga tersebut merupakan segitiga siku siku dengan besar salah satu sudutnya $90^{\circ}$.

\section{Triple Pythagoras}

Tiga buah bilangan $\mathrm{a}, \mathrm{b}$ dan $\mathrm{c}$ dimana $\mathrm{a}$ dan $\mathrm{b}$ bilagan asli dan $\mathrm{c}$ merupakan bilangan terbesar, dikatakan merupakan tripel Pythagoras jika ketiga bilangan tersebut memenuhi hubungan $\mathrm{c}^{2}=\mathrm{a}^{2}+\mathrm{b}^{2}$ atau $b^{2}=c^{2}-a^{2}$ atau $a^{2}=c^{2}-b^{2}$.

\section{Segitiga - Segitiga Istimewa}

Pada segitiga $\mathrm{ABC}$, panjang siku - sikunya $\mathrm{AB}=\mathrm{BC}=$ a maka pajang sisi miringnya adalah $\mathrm{AC}=$ $\sqrt{ }\left(a^{2}+a^{2}\right)=a \sqrt{2}$ Dengan demikian, diperoleh perbandingan sisi - sisinya yaitu AB:BC:AC $=a: a:$ a $\sqrt{2}$. Segitiga istimewa dengan sudut $45^{\circ}, 45^{\circ}$, dan $90^{\circ}$ panjang sisi miring adalah $\sqrt{2}$ kali panjang sisi lain. Segitiga istimewa dengan sudut $30^{\circ}, 60^{\circ}$, dan 90 panjang sisi miring adalah 2 kali sisi terpendek dan panjang sisi lain adalah $\sqrt{ } 3$ kali sisi terpendek.

\section{Motivasi Belajar}

Motivasi belajar adalah dorongan psikologis siswa untuk belajar dengan senang, sungguhsungguh, yang pada akhirnya akan membentuk cara belajar siswa yang penuh konsentrasi, sistematis, serta bisa menyeleksi kegiatan-kegiatannya (Setyowati, 2007). Motivasi belajar menentukan keberhasilan anak dalam belajar, untuk mendapatkan hasil yang sesuai dengan garis-garis besar program pengajaran di sekolah. Adapun indikator motivasi belajar, yaitu (Setyowati, 2007) :

\section{Membangkitkan minat belajar}

Pembelajaran yang dihubungkan dengan minat siswa dapat dilakukan dengan cara menunjukan bahwa pembelajaran yang akan dipelajari itu sangat bermanfaat bagi mereka. Cara lainnya yaitu dengan memberikan siswa pilihan terkait cara-cara mempelajari materi pembelajaran dan materi yang akan dipelajarinya.

\section{Mendorong rasa ingin tahu}

Guru yang terampil harus dapat mendorong rasa ingin tahu siswa di dalam kegiatan pembelajaran. Membangkitkan hasrat ingin tahu siswa dapat menggunakan metode pembelajaran diskoveri, studi kasus, diskusi, inkuiri, curah pendapat, dan sejenisnya.

\section{Menggunakan teknik penyajian yang menarik}

Penggunaan materi pembelajaran dan teknik penyajian yang menarik dapat meningkatkan motivasi belajar siswa.

\section{Membantu siswa dalam merumuskan tujuan belajar}

Apabila tujuan dirumuskan atau ditetapkan oleh diri sendiri dan bukan dirumuskan atau ditetapkan oleh orang lain maka siswa akan belajar keras untuk mencapai tujuan tersebut.Sehngga, termotivas untuk belajar. 


\section{Integrasi Sejarah Phytagoras dalam Pembelajaran Teorema Phytagoras}

Pada perkiraan 800 tahun Sebelum Masehi (SM), di Mesir terdapat permasalahan dalam membuat kuil sebagai tempat kegiatan ibadah yang diharapkan memiliki sesi tegak lurus yang akurat. Para pembuat kuil membangun masing-masing sisi bangunan menggunakan tali yang memiliki perbandingan 3, 4 dan 5. Perbandingan angka 3, 4, dan 5 ini kemudian diberkembangkan di berbagai peradaban yang pada akhirnya dibuktikan dan dikembangkan oleh Pythagoras untuk menentukan panjang sisi-sisi segitiga siku-siku menjadi dalil Pythagoras yang sekarang kita ketahui. Cerita ini menyatakan bahwa pada awalnya konsep matematika tercipta didasarkan kepentingan untuk menyelesaikan suatu permasalahan dalamkehidupan sehari-hari dan berkembang sejalan dengan perkkembangan kebutuhan dan ilmu pengetahuan manusia itu sendiri. (Argaswari, 2018).

Adapun contoh soal yang dapat diterapkan yaitu, "Tono dan kawan - kawan sedang berkemah. Mereka mencoba membangun pondasi untuk membuat tenda dengan menancapkan tiang kayu ke tanah, lalu mengikat ujung tiang dengan tiga buah tali yang sama panjang ke tanah pada tiga arah yang berbeda. Jika jarak pangkal tiang ke masing - masing tali 3 meter dan tinggi tiang tersebut 4 meter. Berapa panjang tali yang dibutuhkan agar tiang tersebut dapat berdiri tegak?".

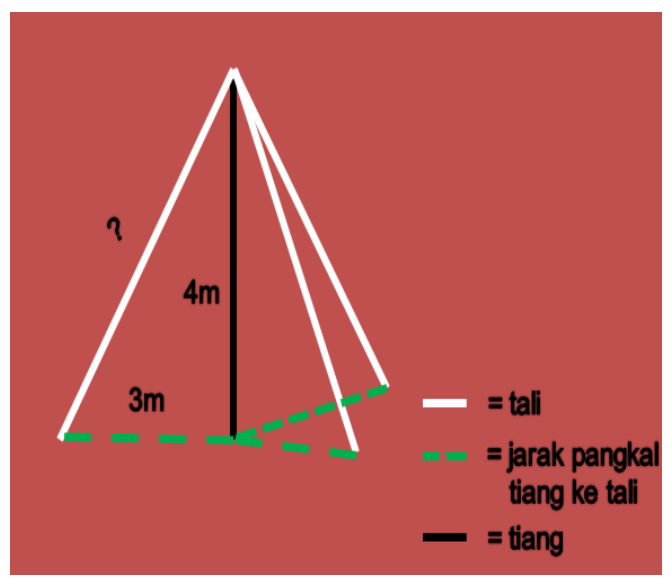

Gambar 1. Penerapan Teorema Phytagoras pada kehidupan sehari - hari

Soal di atas berkaitan dengan minat siswa di bidang pramuka. Selain itu, metode pembelajaran di atas adalah studi kasus yang merupakan langkah yang tepat untuk meningkatkan keingintahuan siswa (Setyowati, 2007), serta dapat dikembangkan lebih luas dalam mengasah kemampuan berpikir kritis matematis (Putri, 2020) dan kemampuan metakognitif siswa (Salsabila, 2019). Metode penyajian soal dengan metode ini juga menarik karena berkaitan dengan kehidupan sehari-hari. Selain itu, siswa juga mencapai tujuan belajar dengan ditetapkan oleh dirinya sendiri. Berdasarkan pernyataan tersebut, maka pengintegerasian sejarah phytagoras dalam pembelajaran memenuhi indikatorindikator motivasi belajar. Sehingga, dapat memotivasi siswa dalam pembelajaran phytagoras.

\section{KESIMPULAN}

Hasil studi pustaka menyatakan bahwa pengintegrasian sejarah matematika dalam pembelajaran matematika dapat memotivasi siswa pada materi phytagoraskarena memenuhi indikator - indikator motivasi belajar. Sejarah matematika sebagai media dalam proses belajar, dapat memberikan pengalaman baru bagi siswa serta membuat pembelajaran matematika lebih bermakna karena dihubungkan dengan kehidupan sehari - hari. Saran untuk penelitian selanjutnya yaitu meneliti pengembangan metode ini pada materi matematika lainnya selain teorema phytagoras. 


\section{REFERENSI}

Argaswari, D. (2018). Integrasi Sejarah Matematika untuk Meningkatkan Atensi Siswa. Indonesian Journal of Mathematics Education, 1(1), 59-65.

Aritonang, K. T. (2008). Minat dan Motivasi dalam Meningkatkan Hasil Belajar Siswa. Jurnal Pendidikan Penabur, 7(10): 11-21.

Cleopatra, M. (2015). Pengaruh Gaya Hidup dan Motivasi Belajar terhadap Prestasi Belajar Matematika. Formatif: Jurnal Ilmiah Pendidikan MIPA, 5(2).

Fiangga, S., Rosyidi, A. H., \& Siswono, T. Y. E. (2017). Perspektif Phylogenesis Dan Ontogenesis Dalam Pengembangan Pembelajaran Matematika Menggunakan Aspek Sejarah Matematika. Aksioma, 6(2), 294-300.

Hamdu, G., \& Agustina, L. (2011). Pengaruh Motivasi Belajar Siswa Terhadap Pestasi Belajar Ipa Di Sekolah Dasar (Studi Kasus terhadap Siswa Kelas IV SDN Tarumanagara Kecamatan Tawang Kota Tasikmalaya). Jurnal Penelitian Pendidikan, 302.

Mappeasse, M. Y. (2009). Pengaruh Cara dan Motivasi Belajar Terhadap Hasil Belajar Programmable Logic Controller (PLC ) Siswa Kelas III Jurusan Listrik SMK Negeri 5 Makassar. Jurnal Medtek 1(2): 1-6.

Pusat Pengembangan Pendidikan Kemendikbud. (2019). Persentase Siswa Yang Menjawab Benar SMP Tahun Ajaran 2018-2019. https://puspendik.kemdikbud.go.id/hasilun/ diakses pada 20 Oktober 2020.

Putri A, Sumardani D, Rahayu W, Hajizah MN. 2020. Kemampuan Berpikir Kritis Matematis Menggunakan Model Generative Learning dan Core (Connecting, Organizing, Reflecting Dan Extending). AKSIOMA: Jurnal Program Studi Pendidikan Matematika 9(1).

Salsabila E, Rahayu W, Kharis SA, Putri A. (2019). Analysis of Mathematical Literacy on Students' Metacognition in Conic Section Material. Journal of Physics: Conference Series, 1417(1): 012057.

Setyowati. (2007). Pengaruh Motivasi Belajar Terhadap Hasil Belajar Siswa Kelas VII SMPN 13 Semarang. Skripsi, Universitas Negeri Semarang.

Siswato, I. (2017). Pengaruh Motivasi Belajar terhadap Hasil Belajar. Jurnal Matematics Pendagogic, 1(2), 180-184.

Wahyu, K., \& Mahfudy, S. (2016). Sejarah Matematika: Alternatif Strategi Pembelajaran Matematika. Beta Jurnal Tadris Matematika, 9(1), 89-110. 